\title{
Understanding General and Specific Intent: Eight Things I Know For Sure
}

\author{
Eric A. Johnson*
}

Judges and scholars alike long have criticized the terminology of "general intent" and "specific intent" as confusing ${ }^{1}$ and perhaps incoherent. ${ }^{2}$ The Model Penal Code's drafters, for example, characterized these terms as "an abiding source of confusion and ambiguity in the penal law." ${ }^{3}$ Even Chief Justice Roger Traynor, who formulated influential definitions of these terms, acknowledged that "[s]pecific and general intent have been notoriously difficult terms to define and apply."

The terminology persists, however. Courts often rely on the distinction between general and specific intent in defining the scope of the voluntaryintoxication defense. ${ }^{5}$ They also sometimes rely on this distinction in defining the scope of the so-called "diminished capacity" defense. ${ }^{6}$ Finally, and perhaps most

\footnotetext{
* Professor, University of Illinois College of Law.

1 See Model Penal Code $§ 2.02 \mathrm{cmt}$. at $231 \mathrm{n} .3$ (1985) (characterizing this terminology as "an abiding source of confusion and ambiguity in the penal law"); Frey v. State, 708 So.2d 918, 92122 (Fla. 1998) (Anstead, J., concurring in part and dissenting in part) ("Since this perplexing division between 'general' and 'specific' is judicially created, we should seriously consider whether now is the time to revise this ill-conceived framework."); State v. Huber, 356 N.W.2d 468, 472 (S.D. 1984) ("Confusion often seems to accompany any attempt to distinguish what is meant by the phrases 'specific intent,' and 'general intent.' The terms have different connotations in different contexts."); Jerome Hall, General Principles of Criminal Law 142 (2d ed. 1960) ("The current confusion resulting from diverse uses of 'general intent' is aggravated by dubious efforts to differentiate that from 'specific intent."').

2 See People v. Burton, 558 N.E.2d 1369, 1378 (Ill. App. Ct. 1990) (Steigman, J., concurring in part, dissenting in part) (asserting that the terminology of general and specific intent is an "archaic relic[], purporting to convey meaning, but in fact conveying none.").

3 Model Penal Code, $\S 2.02 \mathrm{cmt}$. at $231 \mathrm{n} .3$.

4 People v. Hood, 462 P.2d 370, 377 (Cal. 1969) (Traynor, C.J.).

5 See United States v. Veach, 455 F.3d 628, 631 (6th Cir. 2006) (holding that intoxication is admissible to negate specific-intent elements, but not to negate general-intent elements); United States v. Kurka, 818 F.2d 1427, 1432 (9th Cir. 1987) ("In a prosecution for a specific intent crime, voluntary intoxication that precludes the formation of the requisite intent may be established as a defense.”). Courts often make use of this distinction at the direction of the legislature. California's penal code, for example, provides that "[e]vidence of voluntary intoxication is admissible solely on the issue of whether or not the defendant actually formed a required specific intent." CAL. PENAL Code § 29.4(b) (West 2014); see also, e.g., Colo. Rev. Stat. AnN. § 18-1-804 (West 2015); Wyo. STAT. ANN. § 6-1-202(a) (2015).

6 See United States v. Gonyea, 140 F.3d 649, 650 (6th Cir. 1998) ("In the federal courts, diminished capacity may be used only to negate the mens rea of a specific intent crime."); State v.
} 
importantly, they sometimes rely on this distinction in deciding what culpable mental states to assign to the elements of criminal statutes. ${ }^{7}$ In light of the courts' continued reliance on this distinction, lawyers have little choice but to make what sense they can of it.

In this short paper, I'll try to dispel some of the confusion surrounding general and specific intent. I won't try to construct a complete, unitary theory of general and specific intent. Paul Robinson probably was right when he said that this distinction "is a device, conceived at common law, to achieve a certain result rather than reflecting a coherent theory." 8 So any complete, unitary theory of general and specific intent is bound to be misleading. Instead of theorizing, I'm going to confine myself to saying eight things I know (or think I know) about this topic.

\section{THE TERMS “GENERAL INTENT” AND “SPECIFIC INTENT” AREN'T THE NAMES OF MENTAL STATES. RATHER, THESE TERMS TELL US SOMETHING ABOUT THE RELATIONSHIP BETWEEN THE STATUTE'S MENTAL ELEMENTS AND ITS PHYSICAL ELEMENTS.}

The terms "general intent" and "specific intent" don't describe culpable mental states, or at least they don't describe culpable mental states in the way that terms like "purposely," "knowingly," "recklessly," "negligently," "willfully," and "maliciously" do. When a legislature assigns a mental state to an offense-element, it uses terms like "purposely," "knowingly," and "recklessly." It never uses the terms "general intent" and "specific intent." Nor do judges use the terms "general intent" and "specific intent" in instructing juries on the elements of criminal offenses. When judges instruct juries, they too use terms like "purposely," "knowingly," and "recklessly.",

McVey, 376 N.W.2d 585, 588 (Iowa 1985) (holding that evidence of a mental disease or defect is admissible to negate the mens rea elements only of "specific intent crimes," not of crimes "requiring proof only of guilty knowledge or general criminal intent accompanying a prohibited act").

7 See, e.g., United States v. Zunie, 444 F.3d 1230, 1233-35 (10th Cir. 2006) (reasoning that because the crime of "assault resulting in serious bodily injury is a general intent offense," it does not require proof that the defendant actually intended to cause serious bodily injury); Commonwealth v. Ford, 677 N.E.2d 1149, 1152 (Mass. 1997) ("Because assault and battery by means of a dangerous weapon is a general intent crime, there is no requirement that the Commonwealth prove that the defendant had a specific intent to injure the victim."); State v. Moore, 740 N.W.2d 52, 56 (Neb. Ct. App. 2007) (relying on the fact that "first degree assault is a general intent, not a specific intent, crime" in concluding that "[t]he requisite intent for first degree assault relates to the prohibited act, i.e., the assault, and not to the result achieved, i.e., the injury").

8 Paul Robinson, Criminal Law Defenses $\S 65(\mathrm{e})$ at 298 (1984); see also People v. Gutierrez, 180 Cal. App. 1076, 1081 (Cal. Ct. App. 1986) (explaining that "the distinction between general intent and specific intent crimes is at bottom founded upon a policy decision regarding the availability of certain defenses").

$9 \quad$ See United States v. Dougherty, 763 F.2d 970, 974 (8th Cir. 1985) (describing a trend away from use of the terms "general intent" and "specific intent" in jury instructions and "in favor of 
If general and specific intent aren't culpable mental states, though, what exactly are they? The answer is that these terms describe the relationship between an offense's mental elements and its physical elements. This answer deserves explanation, because it's the key to understanding general and specific intent.

First, by "physical elements" I mean the "conduct" elements, "attendant circumstance" elements, and "result of conduct" elements of which criminal statutes are composed. ${ }^{10}$ To illustrate: The crime of drunk-driving homicide essentially has three physical elements: (1) operating or driving a vehicle, which is a "conduct" element; (2) under the influence of alcohol, which is an "attendant circumstance" element; and (3) causing the death of another person, which is a "result" element."

Of course, criminal statutes also have "mental elements." Penal Code, as in many state criminal codes ${ }^{13}$ the mental elements used in defining offenses include "purposely," "knowingly," "recklessly," and "with criminal negligence."14 Criminal codes also occasionally use mental states like "maliciously" or "willfully." The most important thing to understand about all these mental states is that they "do not exist in isolation-instead, they relate to the [physical] elements contained in the definition of the crime." 15 In the criminal law we never speak of mental states like recklessness or negligence except in relation to a particular result or circumstance. This is evident, for example, in the standard definitions of recklessness and criminal negligence, which imply that recklessness and criminal negligence can exist only in relation to a statutorily defined "result" or "circumstance." 16

Because culpable mental states don't exist in isolation but instead attach to the individual physical elements of offenses, one cannot adequately describe an offense merely by listing its physical and mental elements. One has to specify, as well, just how the offense's physical elements are connected to its mental elements. Criminal law is like chemistry: It isn't enough to know of what basic, atomic elements an object is constructed. To understand the object, you also have

instructions that precisely define the requisite mental state of the particular crime charged") (quoting Federal Criminal Jury Instructions of the Seventh Circuit, pp. 81-82 (West Pub. Co. 1980)).

10 See Model Penal Code $§ 1.13(9)$.

11 See, e.g., Idaho Code AnN. § 18-8006(1) (2004); Mich. Comp. Laws AnN. § 257.625(4) (West 2006); Neb. Rev. Stat. AnN. § 28-306(1), (3)(b) (LexisNexis 2009); N.Y. Penal LaW § 125.12(1) (2006); Wyo. STAT. ANN.§ 6-2-106(b) (1997).

12 See Seymore v. State, 152 P.3d 401, 405 (Wyo. 2007).

13 Model Penal Code $\S 2.02 \mathrm{cmt}$. at 233 ("[V]irtually all recent legislative revisions and proposals follow [the Model Penal Code] in setting up general standards of culpability.").

14 Id. § 2.02(2).

15 Rutley v. State, 171 P.3d 361, 363-64 (Or. 2007).

16 Model Penal Code $§$ 2.02(2). 
to know how exactly the atoms fit together to form molecules (or crimes, as the case may be).

To illustrate: Let's return to the offense of drunk-driving homicide. Remember that this offense has three physical elements: (1) operating or driving a vehicle, which is a "conduct" element; (2) under the influence of alcohol, which is an "attendant circumstance" element; and (3) causing the death of another person, which is a "result" element. The statutes defining this offense usually don't mention a mental state. ${ }^{17}$ But let's assume, for the sake of illustration, that we've been reliably informed that the mental state for the offense is "purposely."

Does this description tell us everything we need to know about the offense? No. We can't know how to apply the statute until we know to which of the statute's three physical elements the mental state of "purposely" attaches. It's one thing to say that the defendant has to purposely drive or operate a vehicle. It's another thing entirely to say that he has to purposely cause the death of another person. And it's yet another thing to say that he has to purposely become intoxicated.

It is in resolving this question - "How do the statute's mental elements 'connect up' to its physical elements?" - that the classification of the offense as a general- or specific-intent offense can prove helpful.

\section{WHEN AN OFFENSE REQUIRES PROOF THAT THE DEFENDANT ACTUALLY WANTED TO BRING ABOUT THE SOCIAL HARM AT WHICH THE STATUTE IS TARGETED, THE OFFENSE QUALIFIES AS A SPECIFIC-INTENT OFFENSE.}

So what exactly does the classification of an offense as a general- or specificintent offense tell us about the relationship between the offense's mental elements and its physical elements? For one thing, it sometimes tells us whether the defendant must intend to bring about the social harm that is the target of the statute.

To explain: Every criminal statute is targeted at some form of social harm. ${ }^{18}$ Homicide statutes, for example, are targeted at the social harm of death. ${ }^{19}$ Larceny statutes are targeted at the social harm of permanent (or extended) deprivation of property. ${ }^{20}$ Escape statutes are targeted at the social harm of evasion of justice. ${ }^{21}$

17 See, e.g., IDAHO CODE § 18-8006(1) (2004); Mich. Comp. LAWS AnN. § 257.625(4) (West 2006); Neb. Rev. Stat. AnN. §§ 28-306(1), (3)(b) (LexisNexis 2009); N.Y. Penal LaW AnN. § 125.12(1) (2006); Wyo. STAT. ANN.§ 6-2-106(b) (1997).

18 Joshua Dressler, UNDERSTANDING CRIMINAL LAW 112-16 (5th ed. 2009).

19 Id. at 114.

${ }^{20}$ See Bass v. State, 138 N.W.2d 154, 157 (Wis. 1965) ("The gravamen of larceny is an intention to permanently deprive the owner of possession of his property ...").

${ }^{21}$ See People v. Velarde, 657 P.2d 953, 955 (Colo.1983) ("The fundamental purpose of the [escape] statute is to prevent the evasion of the due course of justice."). 
Some criminal statutes require proof that the defendant actually meant to bring about the social harm that is the target of the statute. For example, the offense of first-degree murder often (though not always) requires the government to prove that the defendant actually meant to bring about the death of another person. ${ }^{22}$ And the offense of larceny often (though not always) requires the government to prove that the defendant intended to deprive the owner of the stolen property permanently. ${ }^{23}$

Offenses like first-degree murder and larceny qualify as specific-intent offenses because they require proof that the defendant actually wanted to bring about the social harm at which the statute is targeted. ${ }^{24}$ It is crimes like these to which the courts are referring when they say (as they often do) that a crime will qualify as a specific-intent offense if it requires the state to prove that the defendant intended to "achieve some additional consequence" beyond the commission of "the proscribed act." 25

This definition of specific intent doesn't mention "social harm," of course. But the concept of social harm helps us make sense of the otherwise blurry distinction between the "proscribed conduct" and an "additional consequence." To illustrate the difficulties that surround this distinction: Imagine a case where the defendant uses a firearm to kill another person. ${ }^{26}$ Let's break his conduct down into several steps: (1) he intentionally squeezes the trigger of the firearm; (2) the firearm goes off, sending a bullet in the direction of the victim; (3) the bullet strikes the victim's body; and (4) the damage inflicted by the bullet causes the victim's death. The act of squeezing the trigger clearly seems to be conduct, rather than a "consequence." By contrast, the death of the victim clearly seems to be an "additional consequence." 27 But what of the two events that intervened between the squeezing of the trigger and the victim's death?

22 Мich. COMP. LAWS ANN. $\$ 750.316$ (West 2004).

23 See, e.g., Ill. Comp. Stat. § 5/16-1(5)(A) (West 2003).

${ }^{24}$ See Carter v. State, 408 N.E.2d 790, 794-795 n.6 (Ind. Ct. App. 1980) (“One is punished for first degree murder, a 'specific intent' offense, only when the actor's shooting the gun (i.e., the voluntary act) was done with the subjective desire to kill a human being (i.e., the prohibited result) (perhaps implied in the statutory word 'premeditation')."); Smith v. State, 398 A.2d 426, 442 (Md Ct. Spec. App. 1979) (classifying larceny as a specific-intent offense, on the ground that it "requires the specific animus furandi or deliberate purpose of depriving the owner permanently of the stolen goods").

25 People v. Hood, 462 P.2d 370, 378 (Cal. 1969) (explaining that a crime will qualify as a specific-intent offense if it "refers to the defendant's intent to ... achieve some additional consequence" beyond "the proscribed act").

${ }^{26}$ See Eric A. Johnson, Rethinking the Presumption of Mens Rea, 47 WAKE FOREST L. REV. 769, 791 (2012) (using same illustration).

${ }^{27}$ See People v. Whitfield, 868 P.2d 272, 278 (Cal. 1994) (classifying murder as a specificintent crime) 
First, is the discharge of the firearm an "additional consequence" for purposes of the definition of specific intent? In purely causal terms, the discharge of the firearm is plainly a "consequence" of squeezing the trigger. What is more, it appears to be a truly separate or "additional" event. After all, sometimes pulling the trigger of a gun causes a gun to discharge, and sometimes it doesn't. Thus, it seems as though a requirement that the defendant intend to discharge the firearm would count as a specific-intent element, rather than general-intent element.

But it doesn't. To illustrate: California has a statute that prohibits "discharging a firearm in a grossly negligent manner." 28 The California courts have held that this statute requires proof that the defendant actually intended that the firearm go off; it is not enough that he intended to squeeze the trigger. ${ }^{29}$ Nevertheless, the courts have said that this statute defines a "general intent crime . . . because its mental state consists of an intent to do the act that causes the harm." ${ }^{\text {"N }}$ Thus, the discharge of the firearm can't be an "additional consequence" for purposes of our definition of specific intent.

So what about the next event in the hypothesized causal sequence-namely, the bullet's initial contact with the victim's body? Does this initial contact qualify as an "additional consequence" for purposes of the standard definition of specific intent? In causal terms, the bullet's contact with the body plainly is a "consequence" both of the squeezing of the trigger and of the firearm's discharge. What is more, this initial contact appears to be a truly separate event. After all, the discharge of a firearm sometimes causes a bullet to strike another person's body, and sometimes doesn't.

Nevertheless, courts uniformly have held - in interpreting battery statutesthat an intent to bring about contact with another person's body is a form of general intent, not specific intent. ${ }^{31}$ This means that in our hypothetical shooting the bullet's initial contact with the other person's body cannot be considered an "additional consequence" for purposes of our definition of specific intent.

So what's going on here? All three of the events that followed the squeezing of the trigger - the discharge of the firearm, the bullet's initial contact with the victim's body, and the death of the victim - appear to be "consequences" of the conduct. So why is only one of these events - the death of the victim - treated as an "additional consequence" for purposes of the standard definition of specific intent? The answer, as you've probably already guessed, is that only the death of

28 CAl. Penal Code AnN. $\$ 246.3$ (West 2014).

29 People v. Robertson, 95 P.3d 872, 879 (Cal. 2004) (holding that a defendant who believed that the firearm was unloaded would not be guilty of violating the statute).

30 People v. Overman, 24 Cal. Rptr. 3d 798, 809 (Cal. App. 4 Dist. 2005).

31 See State v. Campbell, 39 P.3d 97, 100 (Kan. App. 2002) (explaining that intent to "caus[e] physical contact with another person" is a form of general intent); People v. Colantuono, 865 P.2d 704, 709 (Cal. 1994) (same); Commonwealth v. Ford, 677 N.E.2d 1149, 1151-52 (Mass. 1997) (same). 
the victim is really a "social harm" at which the applicable statute is targeted. Statutes that proscribe, say, the intentional discharge of a firearm, or the intentional touching of another person, aren't ultimately targeted at the discharge of firearms or touching. The ultimate social harm at which these statutes are targeted is physical injury to persons. Only if these statutes required proof that the defendant really meant to bring about physical injury, or death, would the offenses qualify as specific-intent offenses. ${ }^{32}$

In summary, when courts say that an offense will qualify as a specific-intent offense if it requires proof that the defendant intended to "achieve some additional consequence" beyond "the proscribed act," what they really mean is that an offense will qualify as a specific-intent offense if it requires proof that the defendant intended to bring about the social harm at which the statute is targeted.

This refinement of the standard definition also has the benefit of giving the distinction between general and specific intent some real intuitive content. There is a very basic, morally intuitive distinction between (1) somebody who really wants to bring about social harm and (2) somebody who merely accepts the possibility of bringing about social harm by, say, intentionally discharging a firearm under dangerous circumstances. There is a difference, as Antony Duff has said, "between being guided by wrong reasons and not being guided by right reasons." 33

\section{SOMETIMES, A SPECIFIC-INTENT OFFENSE-INSTEAD OF REQUIRING PROOF THAT THE DEFENDANT WANTED TO BRING ABOUT THE SOCIAL HARM AT WHICH THE STATUTE IS TARGETED—REQUIRES PROOF THAT THE DEFENDANT “INTENDED TO COMMIT SOME FURTHER ACT.”}

In the last section, I said that the term "specific intent" sometimes is used to refer to crimes that require proof that the defendant actually intended to bring about the social harm that is the target of the statute. It would be nice if these crimes were the only crimes referred to as specific-intent crimes. Unfortunately, things aren't that simple. The term "specific intent" also is used to refer to another, very different category of offenses. Namely, it is used to refer to offenses that require proof that the defendant - in addition to intending to engage in the prohibited conduct - also intended "to do some further act.",34

The classic example of this second type of specific-intent offense is burglary. ${ }^{35}$ Burglary requires, first, that the defendant enter or remain in a building

32 Johnson, supra note 26, at 793.

33 See R.A. Duff, Criminalizing Endangerment, 65 LA. L. REV. 941, 945-46 (2005).

34 People v. Hood, 462 P.2d 370, 378 (Cal. 1969).

35 See State v. Burkley, 804 S.W.2d 458, 461 (Tenn. Crim. App. 1990) ("Burglary qualifies as a specific intent offense; the elements of the crime include the defendant's intent to achieve some result additional to the act. To obtain a conviction, the state must prove that the defendant, at the 
or vehicle without authority. ${ }^{36}$ But the burglary statute requires more than proof that the defendant intentionally engaged in this "prohibited conduct." It also requires proof that the defendant, when he engaged in the prohibited conduct, intended to commit theft or a felony inside the building or vehicle. ${ }^{37}$ This intent to commit larceny or a felony is the "intent to do a further act" that makes burglary a specific-intent offense.

Statutes like this are commonplace. For example, the Illinois statute defining the offense of aggravated kidnapping provides that a person commits this offense if he secretly confines another person against his will with the intent to "obtain[] ransom from the person kidnapped or from any other person." ${ }^{38}$ Under this statute, the prohibited conduct is the confinement of the other person. But the statute requires more than just proof that the defendant performed the prohibited conduct. It also requires proof that the defendant "intended to do some further act," i.e., that he intended to obtain ransom from the person kidnapped or some other person. ${ }^{39}$

It's easy to see that the two categories of specific-intent offenses - those that require "intent to do some further act," and those that require intent to bring about the social harm that is the statute's target - are different in scope. First of all, offenses that require an intent to commit a "further act" don't necessarily require an intent to bring about social harm. The "further act" element of burglary, for example, would be satisfied by the intruder's intent to commit rape, which does not require proof of intent to bring about any social harm and which, accordingly, is classified as a general-intent offense. ${ }^{40}$ This means that a person could be guilty of burglary without actually intending to bring about any social harm.

Second, offenses that require an intent to bring about social harm don't necessarily require an intent to commit a further act. Consider, for example, a case of first-degree murder, where the defendant kills another person by shooting him. The defendant intends - by squeezing the firearm's trigger - to set in motion a chain of events that eventually will lead to the death of another person. $\mathrm{He}$ intends, that is, for the firearm to discharge, for the bullet to strike the victim, and for the bullet to cause fatal injuries to the other person. But he does not and need not intend - when he squeezes the trigger of the firearm - to "commit some further act." His participation in the murder is complete when he squeezes the trigger. In

\footnotetext{
time he entered, intended to commit a felony within the dwelling.") (citations and internal quotation marks omitted).

36 See, e.g., 720 ILL. COMP. STAT. § 5/19-1 (West 2003).

37 Id.

38720 Ill. COMP. STAT. § 5/10-2(a)(1) (West 2003).

39 Id.

40 See People v. Griffin, 94 P.3d 1089, 1093 (Cal. 2004) (“Rape is a general intent offense.”).
} 
a case like this one, then, the specific-intent offense of first-degree murder does not require proof that the defendant "intended to commit some further act."

The difference between the two kinds of specific-intent offenses raises an obvious question: Why are these two different kinds of offenses classified together at all? It's probably impossible to answer this question definitively. But the answer to the question might lie in the historical role played by the distinction between specific and general intent in defining the scope of the voluntaryintoxication defense.

Before the nineteenth century, the common law apparently "made no concession whatever because of intoxication, however gross." ${ }^{.42}$ During the nineteenth century, however, judges in England and the United States began searching for a "more humane, yet workable, doctrine." ${ }^{3}$ An avenue for ameliorating the harsh effects of the common law rule emerged in 1819, when Holroyd, J., held in a murder case that voluntary intoxication, though not a defense, could negate the mental element of premeditation in murder. ${ }^{44}$ The broader theory underlying this decision - that "intoxication could be considered to negate intent, whenever intent was an element of the crime charged"-carried the potential, however, to undermine the traditional rule entirely, since some form of mens rea is an element of nearly every offense. ${ }^{45}$ The basis for a compromise emerged in 1849, when Coleridge, J., said that evidence of voluntary intoxication was relevant only if it deprived the defendant of "the power of forming any specific intention." 46 Other courts quickly seized on this distinction-between "specific intention" and other forms of mens rea - as a way of "limit[ing] the operation of the doctrine and achiev[ing] a compromise between the conflicting feelings of sympathy and reprobation for the intoxicated offender." 47

This historical role - as a vehicle for "achieving a compromise" between complete exculpation of the intoxicated offender and the harshness of the old common-law rule - might explain why the term "specific intent" has come to encompass two very different kinds of mental states. Each of these two mental states is commonly used to distinguish the most serious version of an offense from

41 See also People v. Hesslink, 213 Cal.Rptr. 465, 470-71 (Cal. Ct. App. 1985) (holding that extortion statute's required intent "to obtain property of another" qualified as a specific intent to achieve "a future consequence," even though the statute required that the defendant succeed in "obtaining ... property from another" as part of the proscribed conduct).

42 Jerome Hall, Intoxication and Criminal Responsibility, 57 HARV. L. REV. 1045, 1046 (1944).

43 People v. Hood, 462 P.2d 370, 377 (Cal. 1969).

44 Rex v. Grindley, quoted in Rex v. Carroll, 7 C. \& P. 145, 173 Eng. Rep. 64, 65 (N. P. 1835).

45 Hood, 462 P.2d at 456

46 Regina v. Monkhouse, 4 Cox C.C. 55, 56 (1849).

47 Hood, 462 P.2d at 377 
a less serious version. The intent to bring about the social harm that is the statute's target is used, for example, to distinguish first- from second-degree murder. ${ }^{48}$ Likewise, in some states' battery statutes, the intent to cause serious physical injury is used to distinguish aggravated from simple battery. ${ }^{49}$ The intent "to do some further act" also is sometimes used to distinguish the more serious version of an offense from the less serious. ${ }^{50}$ For example, the intent to hold the victim for ransom or as a hostage is used to distinguish aggravated kidnapping from simple kidnapping. ${ }^{51}$

This means that the law can achieve the desired "compromise" by permitting the defendant to use intoxication evidence to negate either of these two forms of "specific intent." If intoxication evidence is made admissible just to negate either of these two forms of intent, then the law will express sympathy for the gravely intoxicated offender by permitting him to escape punishment for the most serious version of the offense. At the same time, though, it won't permit him to escape punishment entirely.

\section{GENERAL-INTENT OFFENSES USUALLY REQUIRE MORE (BY WAY OF CULPABILITY) THAN A MERE EXERCISE OF VOLITION. AT THE VERY LEAST, THEY \\ REQUIRE SOME BASIC KNOWLEDGE OF THE SURROUNDING CIRCUMSTANCES.}

When called upon to define the term "general-intent offense," courts sometimes say that an offense is a general-intent offense if "it is sufficient to demonstrate that the defendant undertook the prohibited conduct voluntarily, and his purpose in pursuing that conduct is not an element of a crime." ${ }^{, 52}$ This is a very confusing definition, for several reasons. In this section, I'll explain one of these reasons: it appears to equate "general intent" with the requirement of a "voluntary act."

The voluntary-act requirement says that a willed bodily movement is usually an indispensable condition of criminal liability. ${ }^{53}$ This basic point was made a

48 See People v. Langworthy, 331 N.W.2d 171, 178 (Mich. 1982); Commonwealth v. Edward, 555 A.2d 818, 829 (Pa. 1989).

49 See, e.g., People v. McCoy, 944 P.2d 584, 589 (Colo. App. 1997); People v. Sivak, 852 A.2d 812, 815-16 (Conn. App. Ct. 2004).

50 See Thomas v. State, 67 P.3d 1199, 1203-04 (Wyo. 2003) (explaining relationship between offense of "possession with the intent to deliver a controlled substance" and lesser included offense of simple possession).

51 Compare 720 Ill. Comp. Stat. § 5/10-2 (West 2003), with 720 Ill. Comp. Stat. § 5/10-1 (West 2003).

52 Jennings v. State, 806 P.2d 1299, 1303 (Wyo. 1991) (citations omitted); see also Hood, 462 P.2d at 378 (Cal. 1969) (explaining that general-intent requires only "inten[t] to do the proscribed act").

${ }^{53}$ Eric A. Johnson, The Crime That Wasn't There: Wyoming's Elusive Second-Degree Murder Statute, 7 Wyo. L. REV. 1, 13 (2007). 
very long time ago by Aristotle, who illustrated it by saying that the assignment of moral blame would be inappropriate "if [the actor] were to be carried somewhere by the wind, or by men who had him in their power." 54 Aristotle's examples would have to be conceded even today. Thus, a person charged with fishing commercially in a closed area might validly defend by asserting "that he had made the set in legal waters but that his boat had been caused to drift into closed waters by the wind and the tide." ${ }^{55}$ And a person charged with the offense of "appear[ing] in any public place ... [in] a drunken condition" might validly defend by asserting that he had been "involuntarily and forcibly carried to that place by the arresting officer." 56

Though a voluntary act is necessary to justify the imposition of criminal liability, however, it is not close to being a sufficient basis for imposing liability. Oliver Wendell Holmes Jr. said just this more than a hundred years ago in The Common Law. "The act is not enough by itself," he wrote, to justify the assignment of blame or the imposition of criminal liability, even though "[a]n act, it is true, imports intention in a certain sense." the forefinger with a certain force is the same act whether the trigger of the pistol is next it or not." 58 Thus, although a person who intentionally crooks his forefinger has performed a "voluntary act," his "act cannot be wrong, even when done under circumstances in which it will be hurtful, unless those circumstances are or ought to be known." 59

This means that even crimes of general intent require something more by way of culpability than a mere voluntary act. ${ }^{60}$ At the very least, they require some basic knowledge - or imputed knowledge — of the surrounding circumstances. For example, though the crime of negligent discharge of a firearm (as defined in Cal. Penal Code $\S 246.3$ ) is a general-intent offense, it plainly requires more than the voluntary act of "crook[ing] the forefinger with a certain force." It requires, in addition, that the person realize that his forefinger is on the trigger of a gun, and probably requires that he realize the gun is loaded as well. ${ }^{61}$

54 The Nicomachean Ethics of Aristotle, Book III, § 1 (W.D. Ross trans. 1958).

55 Love v. State, 457 P.2d 622, 635 (Alaska 1969) (Nesbett, J., dissenting).

56 Martin v. State, 17 So. 2d 427, 427 (Ala. App. 1944).

57 Oliver Wendell Holmes JR., The COMmON LAW 54 (1881).

$58 \quad$ Id.

59 Id.; see also Glanville Williams, Criminal LaW: The General Part $\S 8$ at 13 (2d ed. 1961) (observing that "[t]he requirement of an act with its element of will is not so important a restriction upon criminal responsibility as it may first appear").

${ }^{60}$ Cf. Wilkerson v. State, 336 P.3d 1188, 1198 (Wyo. 2014) ("Neither the requirement that the defendant 'purposely' perform the act that causes death nor the requirement that the defendant act with 'hatred, ill will, or hostility' is sufficiently demanding to mark the boundary of second-degree murder.") (quoting Johnson, The Crime That Wasn't There, supra note 53, at 47).

61 See People v. Robertson, 95 P.3d 872 (Cal. 2005). 
The same kind of basic knowledge is required for other general-intent offenses, too. Take, for example, the crime of being a felon in possession of a firearm. The courts have recognized that this crime is a general-intent offense. ${ }^{62}$ The courts also have recognized, though, that this offense requires more by way of culpability than a voluntary act. It also requires that the defendant "know[] that the instrument possessed is a firearm." ${ }^{63}$ In other words, it isn't enough that the defendant intentionally performed the bodily movements by which he acquired possession of the thing; he must also know that the thing of which he acquired possession is a firearm.

The crime of battery, too, illustrates why a voluntary act isn't enough. Battery is a general-intent offense, and so it doesn't require proof that the defendant actually intended to bring about the social harm that is the target of the statute ${ }^{64}$ It does, however, require that the "touching" of the victim be intentional; i.e., "the jury must find beyond a reasonable doubt that the touching did not happen accidentally." ${ }^{\prime 65}$ This means that a willed bodily movement-say, the swinging of the defendant's fist - would not be enough to satisfy the mental element of battery. The government also would need to prove that the defendant meant the fist to make contact with the victim.

Don't get me wrong. A voluntary act is definitely a component of generalintent offenses, as it is a component of every offense. And this voluntary-act component probably plays a more important role in cases of general intent than in cases of specific intent, given the relative dearth of other mental elements where crimes of general intent are concerned. But general intent should not be confused with mere volition.

\section{CRIMES OF RECKLESSNESS AND NEGLIGENCE ARE GENERAL-INTENT OFFENSES.}

One of the most confusing aspects of the standard definitions of general and specific intent is that they don't tell us how to classify crimes of recklessness and negligence. According to the standard definitions, a crime will qualify as a "general-intent crime" if it requires only "inten[t] to do the proscribed act." $\mathrm{A}$ crime will qualify as a "specific-intent crime" if it requires, in addition, an "intent to do some further act or achieve some additional consequence." ${ }^{, 97}$

Crimes of recklessness and negligence often satisfy neither of these definitions. ${ }^{68}$ Take, for example, the crime of reckless manslaughter. Reckless

62 See Carfield v. State, 649 P.2d 865, 871 (Wyo. 1982).

63 Poole v. State, 152 P.3d 412, 414 (Wyo. 2007) (citing Carfield, 649 P.2d at 972).

64 See Commonwealth $v$. Ford, 677 N.E.2d 1149, 1152 (Mass. 1997).

65 Id.

66 People v. Hood, 462 P.2d 370, 378 (Cal. 1969).

67 Id.

68 See Paul Robinson, Criminal Law Defenses $§ 65(\mathrm{e})$ (1984). 
manslaughter requires the state to prove, first, that the defendant voluntarily performed that act that caused the victim's death. ${ }^{69}$ But it also requires the state to prove that the defendant was reckless with respect to the social harm - that is, that he consciously disregarded a substantial and unjustifiable risk that his voluntary act would cause another person's death. ${ }^{70}$ By virtue of this requirement of recklessness in relation to the result, the offense seems to require more than general intent - that is, more than "intent to do the proscribed act." At the same time, though, the statute appears to require less than specific intent. Recklessness is not, after all, the equivalent of a requirement that the defendant specifically "intend[] to commit some further act[] or achieve some additional purpose."71 Thus, reckless manslaughter - and indeed any crime whose definition requires knowledge or recklessness or negligence with respect to the social-harm elementfits comfortably neither within the standard definition of general-intent crime nor within the standard definition of a specific-intent crime.

Courts have taken two approaches to the classification of these crimes. Some courts have treated crimes of recklessness as general-intent crimes, on the theory that these crimes do not require proof that the defendant "intended" to bring about the proscribed result. ${ }^{72}$ These courts, in construing the phrase "specific intent," have read the word "intent" in its narrow sense, to refer just to those cases where the proscribed result is the defendant's conscious objective. Under this approach, then, a crime is a "specific-intent crime" only if it requires proof that the defendant specifically "intended" to bring about the social harm that is an element of the offense. A crime is a "general intent crime," by contrast, "if the actor can be convicted upon proof of any lesser state of mind," as where the required mental state with respect to the social harm is "knowingly, recklessly, or negligently.",73

Other courts have, in contrast, treated crimes of recklessness as specific-intent crimes, on the theory that they require proof of something more than a basic knowledge of the surrounding circumstances. ${ }^{74}$ Under this approach, the word "intent" in the phrase "specific intent" is read to refer broadly to any mental state

69 See, e.g., 720 ILl. COMP. STAT. § 5/4-1 (West 2003) (providing that "[a] material element of every offense is a voluntary act").

70 See, e.g., 720 ILl. COMP. STAT. §§ 5/4-6, 5/9.3(a) (West 2003).

71 Jennings v. State, 806 P.2d 1299, 1303 (Wyo. 1991).

72 See, e.g., People v. Carr, 97 Cal. Rptr. 2d 143, 148 (Cal. App. 2000); Holbrook v. State, 772 A.2d 1240, 1250 (Md. 2001); State v. Zanger, 851 A.2d 134, 139 (N.J. Super. Ct. Law Div. 2004); Spicer v. State, 42 P.3d 742, 745 (Kan. App. 2002).

73 Dressler, supra note 18, at 137-38 (3d ed. 2001); cf. Model Penal Code $\S 2.02 \mathrm{cmt}$. at 228 (commenting that " $[\mathrm{t}]$ here is a rough correspondence between this provision [establishing default culpable mental state of recklessness] and the common law requirement of 'general intent'").

74 See State v. Brown, 931 P.2d 69, 75-77 (N. M. 1996). 
at all that attaches to the social-harm element. ${ }^{75}$ Thus, on this approach, if the statute defining the offense requires proof that the defendant acted "purposely," "knowingly," or "recklessly" with respect to the proscribed harm, then the crime is a specific-intent crime. Concomitantly, a crime is a general-intent crime if the statute defining the offense "requires no further mental state beyond willing commission of the act proscribed by law." $" 76$

The first of these two views is correct, I think. In the remainder of this section, I hope to show why crimes of recklessness and negligence bear a deep similarity to standard-issue general-intent offenses, and why this deep similarity justifies classifying crimes of recklessness and negligence as general-intent crimes.

Let's begin by taking yet another look at a standard-issue general-intent offense: drunk-driving homicide. Most state criminal codes have a statute defining the offense of drunk-driving homicide, in which the driver's liability for homicide hinges exclusively on his intoxication at the time of the fatal accident. ${ }^{77}$ These statutes do not require the jury to make a determination that the defendant was reckless or negligent with respect to the result element, i.e., the death of a person. ${ }^{78}$ Instead, the statutes' only required mental states pertain to the conduct and attendant-circumstance elements. They usually require, first, that the defendant act purposely with respect to the conduct element (namely driving a motor vehicle) and, second, that the defendant act knowingly with respect to an attendantcircumstance element (namely, the fact that the defendant had consumed an intoxicant).

A second, related example of a general-intent offense is the crime of druginduced homicide. Some state legislatures have specific drug-induced homicide statutes that supplement the states' broader general proscription on reckless homicide. ${ }^{79}$ These statutes generally require, first, that the defendant deliver one of several specified controlled substances-e.g., heroin, methamphetamine, or cocaine - and, second, that another person die as the result of ingesting the

75 See Wayne LaFave, Criminal LaW $\S 5.2$ (e) at 252 (4th ed. 2003) (acknowledging that "the phrase 'criminal intent' is sometimes used to refer to criminal negligence and recklessness"); see also Dean v. State, 668 P.2d 639, 642 (Wyo. 1983).

76 People v. Sargent, 970 P.2d 409, 414 (Cal. 1999).

77 See, e.g., Fla. Stat. § 316.193(3)(c)(3) (2011); IdAHo COdE § 18-8006 (2004); Mich. Comp. L. § 257.625(4) (West 2006); NeB. Revised Stat. § 28-306(1), (3)(b) (LexisNexis 2009); N.Y. PENAL LAW § 125.12(1) (2006).

78 See Allen v. State, 43 P.3d 551, 569 (Wyo. 2002); see also, e.g., People v. Garner, 781 P.2d 87, 89 (Colo. 1989); State v. Hubbard, 751 So.2d 552, 563 (Fla.1999); State v. Creamer, 996 P.2d 339, 343 (Kan. 2000); Reidweg v. State, 981 S.W.2d 399, 406-07 (Tex. App. 1998).

79 See, e.g., Alaska Stat. § 11.41.120(a)(3) (West 2006); Colo. Revised Stat. § 18-3102(e); Fla. Stat. § 782.4(3) (West 2015); 720 Ill. Comp. Stat. § 5/9-3.3 (West 2003); La. Stat. § 14:30.1(3) (2011); MinN. STAT. § 609.195(b) (2015); N.J. STAT. § 2C:35-9 (2009); 18 R.I. Gen. LAWS § 11-23-6 (2013); TENN. CODE § 39-13-210 (2010); 18 VT. STAT. § 4250(a) (2011); Wash. REVISED CODE. $\S 69.50 .415$ (West 2004). 
controlled substance. The statutes do not require the government to prove that the defendant was reckless or negligent with respect to the social harm that is the target of the statute ${ }^{80}$ Instead, by way of mens rea, they typically require the government only to prove that the defendant knew that he or she was delivering the controlled substance. ${ }^{81}$

At first glance, crimes like drunk-driving homicide and drug-induced homicide appear to have different structure than crimes like reckless manslaughter and criminally negligent homicide. ${ }^{82}$ In terms of culpability, drunk-driving homicide and drug-induced homicide require nothing more than voluntary conduct together with a basic knowledge of the surrounding circumstances. They do not require the government to prove a culpable mental state with respect to the fact that arguably is the principal determinant of liability: the death of a person. In stark contrast, the offenses of reckless manslaughter and criminally-negligent homicide do require the government to prove a culpable mental state-recklessness or criminal negligence - with respect to this critical element.

But there is another way of looking at this. As Professor Mark Kelman has pointed out, offenses like drunk-driving homicide and drug-induced homicide are related to reckless and criminally negligent homicide in the same way that negligence per se is related to ordinary negligence. ${ }^{83}$ What differentiates drunkdriving homicide and drug-induced homicide from reckless manslaughter and criminally negligent homicide is just the identity of the decision-maker. Instead of requiring a jury to make an ad hoc, case-by-case determination of unreasonableness, these statutes "require an antecedent [legislative] judgment of per se unreasonableness." 84 The legislature, not the jury, assumes the responsibility for balancing the three factors in the reasonableness calculus: the social utility of the actor's conduct; the gravity of the potential harm; and the probability that the harm will come about as a result of the conduct.

What drives this antecedent legislative determination of per unreasonableness is, not coincidentally, the defendant's basic knowledge of surrounding circumstances. When a trial jury makes an ad hoc, case-by-case reasonableness

80 See People v. Faircloth, 599 N.E.2d 1356, 1360 (Ill. App. 1992); Eric A. Johnson, Mens Rea for Sexual Abuse of a Minor: The Case for Defining the Acceptable Risk, 99 J. CRIM. L. \& CRIMINOLOGY 1, 13 (2009).

81 Johnson, supra note 80.

82 Id.

83 Mark Kelman, Strict Liability: An Unorthodox View, in 4 Encyclopedia of Crime and Justice 1512, 1516 (Sanford H. Kadish ed., 1983). See also Johnson, supra note 82, at 16-18 (developing same point); Guyora Binder, Making the Best of Felony Murder, B.U. L. Rev. 403, 403 (2012) ("[Felony murder] may nevertheless condition liability on moral fault by substituting a per se culpability rule for a culpability standard."); Richard Wasserstrom, Strict Liability in the Criminal Law, 12 Stan. L. Rev. 731, 744 (1960) (arguing that "strict liability statutes require an antecedent [legislative] judgment of per se unreasonableness").

84 Wasserstrom, supra note 83 at 744. 
determination in a prosecution for reckless or negligent homicide, its determination is based on what the defendant knew of the surrounding circumstances. ${ }^{85}$ Likewise, when the legislature makes an antecedent legislative judgment of unreasonableness per se, its determination is based on what the defendant knew of the surrounding circumstances. That's why the crimes like drunk-driving homicide require basic knowledge of the surrounding circumstances, e.g., the fact that one is driving a car, the fact that one has consumed an intoxicant. It's these facts that supply the basis for the legislature's antecedent determination that the defendant knew or should have known of the risk. The statute defining drunkdriving homicide represents a legislative determination that anybody who knows he is driving and knows he has consumed an intoxicant is necessarily reckless or negligent per se.

The same thing can be said, moreover, of pretty much any general-intent offense. The offense of drunk driving, for example, is just the inchoate version of drunk-driving homicide, and the offense of drug-trafficking is just the inchoate version of drug-induced homicide. Both of these offenses, like their choate versions, represent antecedent legislative determinations that the activities in question create unreasonable risks per se. I could go on and on: The offense of being a felon in possession of a firearm represents a legislative determination that felons who possess firearms create an unreasonable risk of harm to other persons. ${ }^{86}$ The offense of battery represents a legislative determination that intentional touching of another person creates an unreasonable risk of physical harm to the person. At the core of the concept of general intent - as that term is used by judges today - is the idea of unreasonable risk-creation. ${ }^{87}$

This is why it makes sense to treat offenses of criminal negligence and recklessness as general-intent offenses. As I said above, in Section 2, the distinction between general and specific intent mostly tracks the very basic, morally intuitive distinction between (1) somebody who really wants to bring about social harm and (2) somebody who merely creates an unreasonable risk of social harm. ${ }^{88}$ Offenses like negligent homicide and reckless manslaughter are risk-creation offenses, just like drunk-driving homicide and drug-induced homicide. So they belong on the risk-creation side of this divide, along with offenses like drunk driving and drug dealing.

85 See Model Penal Code, § 2.02(2)(c)-(d) (defining "recklessly" and "negligently" to require consideration of "the circumstances known to [the defendant]"); see also Eric A. Johnson, Knowledge, Risk, and Wrongdoing: The Model Penal Code's Forgotten Answer to the Riddle of Objective Probability, 59 Buff. L. REv. 507 (2011) (explaining and defending this aspect of the Model Penal Code).

${ }^{86}$ Michael S. MoORE, ACT AND CRIME 21(1993) ("“I]t is to prevent violence that there are various crimes for possession of certain weapons by certain classes of people[.]").

87 Cf. Larry Alexander \& Kimberly Kessler Ferzan, Culpable Acts of Risk Creation, 5 ОніО ST. J. CRIM. L. 375, 376 (2008) (identifying culpable risk-creation as the target of the criminal law).

88 See R.A. Duff, supra note 33 at $945-46$. 
6. You should avoid the temptation to talk about general-intent offenses in terms of "implied," "inferred" or "presumed" intent.

When courts talk about general-intent offenses, sometimes they talk about them in terms of "implied" or "inferred" or "presumed" intent. For example, in Slaughter v. State, ${ }^{89}$ the Wyoming Supreme Court said that "[f]or general intent crimes [the jury only has to find that the act was done voluntarily] because if the act was done voluntarily, "the inference thereupon arises that the defendant intended that which resulted." And likewise in Matlack v. State, ${ }^{90}$ the court said that "general intent is presumed by simply showing that the defendant engaged in the prohibited conduct."

It's easy to understand why courts talk like this. As I explained in the previous section, traditional general-intent offenses like battery and drunk-driving represent antecedent legislative determinations that the conduct in question poses an unreasonable risk of social harm per se. In effect, then, the legislature-when it creates these offenses - "presumes" that anybody who engages in the statutorily defined conduct with knowledge of the surrounding circumstances is at least reckless or criminally negligent with respect to the social harm.

Still, this way of talking is potentially confusing. First of all, there isn't actually a "presumption" at work in these cases..$^{91}$ In criminal cases, a "presumption" generally operates as a permissive inference; the jury is instructed that "it may regard the basic facts as sufficient evidence of the presumed fact but is not required to do so." ${ }^{92}$ The jury, then, retains the ultimate responsibility for deciding whether the presumed fact has been proven. This isn't true in a prosecution for, say, drunk-driving homicide. In a prosecution for drunk-driving homicide, the jury is not instructed that it may infer recklessness from (1) the defendant's knowledge that he was operating a motor vehicle and (2) his knowledge that he had consumed an intoxicant. Rather, the question of recklessness isn't submitted to the jury at all.

Lawyers sometimes refer to statutes like this one as setting up a "conclusive" or "irrebuttable" presumption. But there's nothing to be gained by talking this way. In truth, the antecedent legislative determination of recklessness or negligence per se just removes the ultimate determination of recklessness or negligence from the definition of the offense entirely. As a matter of substantive

89629 P.2d 481, 483-84 (Wyo. 1981) (quoting Dorador v. State, 573 P.2d 839, 843 (Wyo. 1978)).

90695 P.2d 635, 636-37 (Wyo. 1985).

91 See Legille v. Dann, 544 F.2d 1, 5 n.24 (D.C. Cir. 1976) (distinguishing true presumption from "“conclusive' presumption, which is actually a substantive rule of law").

92 Proposed FED. R. EVID. 303(c) reprinted in 56 F.R.D. 183, 212 (1973); see also KENNETH S. BROUN ET AL., MCCORMICK ON EVIDENCE $\S 346$ at 527 (6th ed. 2006) (observing that presumptions in criminal cases are "[i]n most instances" implemented by jury instructions that permit, but do not require, the jury to infer one fact from another). 
criminal law, then, the offense of drunk-driving homicide has two mental elements, not three. ${ }^{93}$

7. General intent isn't fungible. In other words, the mens rea for one general-intent offense can't be substituted for the mens rea of another.

In trying to make sense of the concept of general intent, law students sometimes take the word "general" in the wrong way. The word "general" can mean "not confined by specialization or limitation." 94 And so students sometimes think that general intent is essentially fungible. In other words, students sometimes think that the mens rea component of a general-intent offense will be satisfied by any kind of culpability at all.

Let me illustrate what I mean by fungible. Consider the classic case of Regina v. Pembliton. ${ }^{95}$ Pembliton got into a fight with a group of people on a street lined with houses. In the course of the fight, Pembliton picked up a stone and threw it at the group. The stone flew over their heads and struck and broke a glass window of one of the nearby homes. Pembliton was charged with the statutory offense of "unlawfully and maliciously committing damage ... to the property of another." At Pembliton's trial, the prosecuting attorney did not argue that Pembliton had intended to break the window, nor did he argue that Pembliton had been reckless with respect to the possibility that the rock would break a window. Rather, he argued that Pembliton's intent to physically injure one of his opponents sufficed to establish the mens rea element of the malicious damage statute. He assumed, then, that an intent to commit assault or battery would also satisfy a statute prohibiting property damage.

He was wrong, as it turned out. But his assumption had a historical basis. At common law, it apparently was not a defense to a general-intent crime that the defendant reasonably believed that he was engaged in committing an offense different or less serious than the charged offense. ${ }^{96}$ The defendant, it was said, "cannot set up a defence by merely proving that he thought he was committing a

93 See Ronald Allen \& Lee Ann DeGrazia, The Constitutional Requirement of Proof Beyond a Reasonable Doubt in Criminal Cases: A Comment on the Incipient Chaos in the Lower Federal Courts, 20 AM. CRIM. L. REV. 1, 13 (1982) (arguing that creation of a "conclusive presumption" of intent really just removes intent element from the definition of the crime: "This involves no burden shifting at all; the issue has simply been removed as an [element of the offense]."); People v. Dillon, 668 P.2d 697, 717 (Cal. 1983) ("We are led astray if we treat the 'conclusive presumption of malice' as a true presumption; to do so begs the question whether malice is an element of felony murder.").

94 General, Merriam-Webster's Collegiate Dictionary 484 (10th ed. 1999).

9512 Cox C.C. 607 (1874).

96 See Norman Finkel \& Jennifer Groscup, When Mistakes Happen: Commonsense Rules of Culpability, 3 Psychol. PuB. POL'y \& L. 65, 73-74 (1997) (identifying lesser-moral-wrong and lesser-legal-wrong doctrines as features of the common law's treatment of "general-intent offenses"). 
different kind of wrong from that which in fact he was committing." 97 The culpability required for general-intent crimes was, then, literally "general," rather than "specific"; any sort of blameworthy mental state at all would supply the requisite "general intent." 98

"General intent" in this sense belongs to another era. The old, vague requirement of wickedness-in-general gradually has been replaced by offensespecific and even element-specific culpability. This modern approach to culpability finds expression not only in statutes defining specific offenses but in the statutory definitions of standard mental states like recklessness and criminal negligence. These definitions, again, require the government to prove that the defendant either consciously disregarded or culpably overlooked the specific results or circumstances "described by the statute defining the offense."

8. When criminal statutes are silent or ambiguous about the required mens rea for an offense, courts sometimes presume that the legislature meant to require general intent, rather than specific intent.

In the introduction, I mentioned that courts often rely on the distinction between general and specific intent in deciding what culpable mental states to assign to the elements of criminal statutes. At first glance, this seems backward. After all, the classification of an offense as a general- or specific-intent offense depends, in the first instance, on what mental states are assigned to the offense's elements. How, then, could a court charged with interpreting a statute rely on the offense's classification as a general- or specific-intent offense unless it already knew what culpable mental states were assigned to the offense's elements?

The answer is that courts often presume-before they've interpreted a statute - that the statute requires only general intent. ${ }^{100}$ Criminal statutes often are silent or ambiguous on the subject of mens rea. ${ }^{101}$ So the responsibility for deciding what mental state, if any, to assign to a particular offense-element often devolves upon the courts. ${ }^{102}$ In discharging this responsibility, courts often apply

97 Regina v. Prince, 2 Crim. Cas. Res. 154 (1875).

98 This might also be thought to explain why voluntary intoxication did not negate general intent: the blameworthiness associated with the decision to become intoxicated supplied the requisite degree of general blameworthiness. See Frank Remington \& Orrin Helstad, The Mental Element in Crime - A Legislative Problem, 1952 WIS. L. REV. 644, 649 (1952).

99720 Ill. Comp. Stat. $\S 5 / 4-6,5 / 4-7$ (West 2003).

100 See Carter v. United States, 530 U.S. 255, 268 (2000) ("[T] he presumption of scienter demands only that we read [18 U.S.C. $\S 2113(\mathrm{a})$, which defines the federal bank robbery offense] as requiring proof of general intent.").

101 See Dan M. Kahan, Is Chevron Relevant to Federal Criminal Law?, 110 HaRv. L. Rev. 469, 477 (1996) ("Congress is notoriously careless about defining the mental state element of criminal offenses.”).

102 Johnson, supra note 26 , at 770. 
the so-called "presumption in favor of scienter."103 At least in its traditional form, however, the presumption in favor of scienter just tells the courts that every offense requires "some mental element." 104 It doesn't tell the court which of the offense's physical elements require mental states. ${ }^{105}$ Nor does it tell the court which mental state - purposely, knowingly, recklessly, etc.- to assign. In resolving these questions, courts "generally presume that proof only of 'general' rather than of 'specific' intent is required." 106

To illustrate: The presumption of general intent played a role in the Supreme Court arguments last term in Elonis v. United States. ${ }^{107}$ The petitioner in Elonis, Anthony Elonis, had been charged under 18 U.S.C. $\S 875$ (c) after posting threats to his ex-wife on Facebook. ${ }^{108}$ By its terms, $\S 875(\mathrm{c})$ prohibits "transmit[ting] in interstate or foreign commerce any communication containing any threat to kidnap any person or any threat to injure the person of another." The question that eventually reached the Supreme Court was what mental state or states this statute requires of the defendant. ${ }^{109}$ Elonis argued that the statute required proof that the defendant has acted with "intent to cause fear." 110 By contrast, the government argued that, "it is sufficient that a defendant knew the meaning and context that made his words a true threat, whether or not he subjectively intended them as such." 111 In support of its position, the government invoked the presumption of general intent. ${ }^{12}$

The government's argument, though it ultimately did not carry the day, ${ }^{113}$ nicely illustrates the potential utility of the presumption. If the Supreme Court were to adopt Elonis's interpretation, the crime defined in $\S 875$ (c) would qualify as a "specific-intent crime" in not one but both senses of the term. First, as interpreted by Elonis, $\S 875(\mathrm{c})$ would require the government to prove that the

103 Carter, 530 U.S. at 256-57 (2000).

${ }^{104}$ Morissette v. United States, 342 U.S. 246, 250-52 (1952).

105 Johnson, supra note 26, at 771.

106 United States v. Francis, 164 F.3d 120, 121 (2d Cir. 1999); see also Carter, 530 U.S. at 268; United States v. Campa, 529 F.3d 980, 1006 (11th Cir. 2008); United States v. Jackson, 248 F.3d 1028, 1030-31 (10th Cir. 2001); United States v. Myers, 104 F.3d 76, 81 (5th Cir. 1997), cert. denied, 520 U.S. 1218 (1997); United States v. Martinez, 49 F.3d 1398, 1401 (9th Cir. 1995); United States v. DeAndino, 958 F.2d 146, 148 (6th Cir. 1992); United States v. Lewis, 780 F.2d 1140, 1142 43 (4th Cir. 1986); State v. Dolsby, 145 P.3d 917, 919-20 (Idaho Ct. App. 2006); State v. Buchanan, 549 N.W.2d 291, 294 (Iowa 1996); State v. Warner, 564 N.E.2d 18, 48 (Ohio 1990).

$107 \quad 135$ S. Ct. 2001 (2015).

${ }^{108}$ Id. at 2005-07.

109 Id. at 2004.

110 Brief of Petitioner at 19, Elonis v. United States, 135 S. Ct. 2001 (2015) (No. 13-983).

11 Brief of Respondent at 15, Elonis, 135 S. Ct. 2001 (2015) (No. 13-983).

112 Id. at 28

${ }^{113}$ Elonis, 135 S. Ct. at 2012. 
defendant intended to bring about the social harm that is the target of the statute namely, the fear that generally is engendered by threats of kidnapping or physical injury. Second, as interpreted by Elonis, $\S 875$ (c) would require the government to prove that the defendant intended to bring about a physical state of affairs that is not itself an element of the offense-namely, fear. The presumption of general intent appears strongly to disfavor Elonis's interpretation, then.

The Elonis case also illustrates the limitations of this presumption as a tool of statutory interpretation, however. General-intent offenses take a variety of forms. Often, then, more than one interpretation of an offense-defining statute will be consistent with the offense's presumptive classification as a general-intent offense. In Elonis, for example, the government's interpretation of the statute, which would have required the government to prove only that the defendant "knew the meaning and context that made his words a true threat," presumption of general intent. But so would another viable interpretation, namely, one requiring the government to prove that the defendant was reckless with respect to whether his words would be perceived by the victim as a threat. ${ }^{115}$ The presumption of general intent supplies no basis for choosing between these two interpretations. For this reason, the presumption is less useful than, say, its Model Penal Code counterpart, ${ }^{116}$ which definitively specifies the mental staterecklessness - that attaches to offense-elements that otherwise would lack a mental state.

114 Brief of Respondent, supra note 111.

115 Elonis, 135 S. Ct. at 2012-13 (discussing the possibility of interpreting the statute to require "a finding of recklessness"). Though the Supreme Court rejected the government's interpretation of the statute, it did not decide between two other viable interpretations of the statute: (1) one requiring the government to prove that the defendant meant his words to be perceived as a threat; and (2) another requiring the government to prove that the defendant was reckless with respect to whether his words would be perceived as a threat. Id.

116 Model Penal Code $\S 2.02(3) \& \mathrm{cmt} .5$ (characterizing $\S 2.02(3)$ as "accept[ing] as the basic norm what usually is regarded as the common law position," i.e., the presumption of general intent). 